\title{
Disposal of asbestos and products containing asbestos in Poland
}

\author{
Daniela Szymańska ${ }^{1} \cdot$ Aleksandra Lewandowska $^{1}$
}

Received: 8 November 2017 / Accepted: 26 September 2018 / Published online: 1 October 2018

(c) The Author(s) 2018

\begin{abstract}
The paper makes analyses and evaluation of work progress in asbestos inventory, as well as removal asbestos and asbestos products in Poland in regional scale (i.e., the voivodeships - the state reported until 30th June 2017). Factors, both the ones which caused asbestos 'presence' in Poland related with historical conditioning (i.e., various level of asbestos implementation in economy, building, industry, etc.), but also strictly economic factors, observed in the country after First and Second World War and which at present influence quantity of asbestos removed, were discussed. It was clearly observed in the light of research that quantity of asbestos and asbestos-derived products is significantly much higher in eastern and central regions of Poland, which is a consequence of historical-economic conditions. Moreover, it was indicated that the goals included in 'The Program for Asbestos Abatement in Poland for 2009-2032' have not been implemented with expected results. Slow rate of asbestos and products containing asbestos removal in the country makes us suppose that the goals of 'The Program for Asbestos Abatement in Poland for 2009-2032' will not be completed successfully.
\end{abstract}

Keywords Asbestos $\cdot$ Asbestos cement (eternit) $\cdot$ Neutralization $\cdot$ Hazardous waste $\cdot$ Waste management

\section{Introduction}

Asbestos is a general trade and legal definition for a group of fibrous silicate minerals with crystalline structure and by definition have lengths $>5 \mu \mathrm{m}$ and aspect (length/diameter) ratios of three or greater [1]. Its commercial use started in 2nd half of 19th c, together with the development of demand for insulation for the burgeoning steam technology [1]. Its production and use zenith in Europe, North America and Australia was reported during the $60 \mathrm{~s}, 70 \mathrm{~s}$ and $80 \mathrm{~s}$ of twentieth century $[2,3]$. Together with common asbestos exploitation, the material releasing to the air took place, which resulted in negative influence on human health as well as on other components of natural environment.

Asbestos, due to its properties, i.e., high tensile strength, poor thermal conductivity, sound absorbing properties and relative chemical resistance [4] became very popular

Aleksandra Lewandowska

amal@umk.pl

Daniela Szymańska

dani@umk.pl

1 Department of Urban Studies and Regional Development, Faculty of Earth Sciences, Nicolaus Copernicus University, ul. Lwowska 1, 87-100 Toruń, Poland material not only in industry, but also in products of everyday life. Its common use in building (asbestos-cement tiles and pipes), in power engineering (high chimneys, where dilatations are filled with asbestos ropes, heating routes insulation-asbestos-cement coats), in transport industry (engine thermal insulations of motor vehicles and exhaust manifolds), in chemical industry (asbestos membranes used in electrolytic chlorine production), in military sector, in textile industry (incombustible textiles used by firemen), but also in other branches of national economy, made asbestos the cause of many negative phenomena and processes [5-10].

It is difficult to state univocally the scale of asbestos mining and exploitation. Vogel [11] estimates that world mining until 2000 reached about 174 million $t$ (ton) of asbestos (while from 2000 to 2015 annual asbestos production reached about 2 million t-Fig. 1), with significant participation of the past block of socialistic countries, including Poland with a relatively high ratio. Social-economic development dynamism of socialistic countries, where asbestos was commonly used for industrial and building purposes made this material very popular and it was also imported to Poland (mainly in the period between the $70 \mathrm{~s}$ until the $90 \mathrm{~s}$ of twentieth century, when the Act was passed on 19th June 1997, banning implementation of products containing asbestos), what does not mean, of course, that it had 


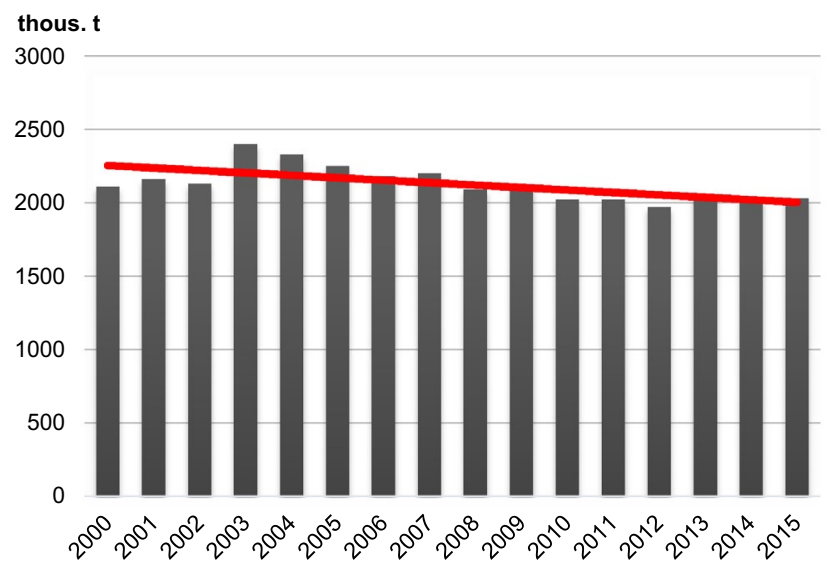

Fig. 1 World asbestos production. Source: own study based on the data [14]

not been used earlier, after First and Second World War. As Szeszenia-Dąbrowska and Sobala state [12]. Polish territory (according to estimations made in 2002) reported about 15.5 million $t$ of products containing asbestos. Destructive influence on human health of asbestos and asbestos products made majority of the world countries prohibit its usage. As it was mentioned above, Poland also introduced in 1997 the legislation prohibiting using products containing asbestos, introducing them to the market, as well as restrictions on production and purchase. Poland, which became a member of European Union in 2004 is obliged to follow the Union legislation (since 1st January 2005), which prohibits producing and purchasing asbestos products obligatory for all EU countries and complete neutralization of the products and their waste until 2032. Furthermore, Polish government introduced in 2002 a document defining management and course of removing asbestos from the country economy, performed as 'The Nationwide Program for Asbestos and Asbestos Products Abatement', which is continued in present 'Program for Asbestos Abatement in Poland for 2009-2032' [13]. Completing the goals of the other program (due to relatively long - at least 30 year durability of asbestos-cement boards and other asbestos materials used in building) was prolonged until 2032.

It should be pointed out, that asbestos negative effects on human health is the issue the most often discussed by scientists, politicians and practitioners, both in Poland and the world [12, 15-24]. Pathogenic asbestos impact is the reason of many diseases, such as: asbestosis, idiopathic pulmonary fibrosis, mesothelioma and other types of cancer by inhaling asbestos fibres present in the air [25-28]. These are respirable fibres, invisible to the naked eye, with the diameter of $<3 \mu \mathrm{m}$ and length of $>5 \mu \mathrm{m}$, creating asbestos dust [12]. Biological aggressiveness of asbestos dust is related with the level of penetration and quantity of fibres in lower part of a respiratory system.
Due to asbestos harmfulness, both at the mining stage and its use in various products (over 3000), present tendency is to make careful inventories of both processes [29]. In this context, it is vital to register asbestos quantities in particular countries (as one of pathogenic factors), remove and neutralize asbestos products, build and shape social awareness concerning knowledge on asbestos danger, especially, as some countries, like: India and China are still using asbestos as building material [30]. The most important asbestos producers include at present Russia, Brasil, China, and Kazakhstan, where manufacturing the material in 2015 amounted, respectively: $650,270,210$ and 180 thous. $t$ [31].

The paper goal is to analyze and estimate work progress in asbestos inventory making, removing asbestos products in Poland in regional scale (i.e., voivodeships-the state until 30th June 2017). Factors which contributed to asbestos 'presence' in Poland resulting from historical conditions (i.e., various intensity of asbestos use in national economy, building, industry, etc.) and economic problems which Poland had to face after First and Second World War and which are still the consequences of these facts defining quantities of removed and neutralized asbestos at present, are discussed.

The work authoresses try to answer the following questions:

- What was the size and dynamism of changes in asbestos use in Poland in twentieth century?

- What is the scale of listed asbestos quantities in Poland until the half of 2017 and what is its regional diversity?

- Is there any dependence between listed asbestos quantities and the mass still waiting for removal and the level of urbanization (percentage of population inhabiting cities) and if there is any correlation between listed asbestos quantity and still waiting for removal and a number of buildings erected between 1970 and 1988 (when asbestos was commonly used as building and engineering constructive material)?

- How many waste dumps, where asbestos is stored and neutralized, are there in Poland and what is their localization and how much of that harmful material has been disposed (stored) until presence?

\section{Source material and methods}

Basic data source for defining asbestos quantity is derived from information collected by a special organizational group, created by the Ministry of Development for collecting and processing information concerning listing asbestos-containing products, but also monitoring the tasks resulting from 'The Program of Asbestos Abatement in Poland for 2009-2032'. The group created Asbestos 
Base which is still updated. The scale of listed asbestos is performed by filling annual information form in which an owner, manager or property user reports to proper authority (mayor, town president or directly a marshal) locations, where asbestos or products containing asbestos were or are still in use. It should be remarked here that by the end of June 2017 The Asbestos Base included as many as 2472 gminas (communes) (for total of 2478 communes in Poland, what is $99 \%$ of that number). Only six communes did not report asbestos presence or local administrative authorities did not report its presence to the Base. Data from Asbestos Base are completed with information obtained by the authoresses during field enquiries made from February until June 2017 in Torun, Bydgoszcz and Włocławek. These queries indicated that locations defined in The Asbestos Base as places containing asbestos and requiring its urgent removal did not contain asbestos any longer, which shows that data base is not always a reliable source. The observation leads also to conclusion that rural property owners are more disciplined in reporting proper authorities asbestos presence or its removal, while in urban spaces, this negligence often results from lack of information, where the fact of removing asbestos material should be reported. In majority of Polish cities listed asbestos is classified as very urgent to be removed and although it has already been disposed, the facts have not been reported to the Base. Poland uses three levels of urgency in asbestos removal, expressed by three information colors: red, orange and yellow.

Taking the above circumstances into account (reliability and data accuracy and completion) it should be remarked that as far as asbestos disposal is concerned Asbestos Base reliability is about $70 \%$, what we especially point out, because if we look at all listed asbestos, we have $100 \%$ of completion and reliability. Despite the fact that a number depicting asbestos disposal is underestimated (30\%), the other $70 \%$ is credible and lets us on this ground define directions of further asbestos removal and neutralization (storage) in Poland.

The authoresses use in the elaboration various methods of the obtained results quantification, processing and presentation. To characterize some dependences between quantity of listed asbestos and selected social-economic features (urbanization level, a number of buildings erected between 1970 and 1988, when asbestos was rather commonly used for building and constructive-engineering purposes), correlation coefficients were measured (with statistical significance $0.001 \%$ ) and coefficient of determination. Furthermore, regression analysis was made, taking into account quantity of listed (designed for disposal) asbestos and percentage of urban populations.

\section{Results and discussion}

\section{Asbestos and products containing asbestos in Poland-imported problem in socialistic countries}

Economy of every country is based on human and natural resources-local or imported, as not all country resources are sufficient for industrial exploitation and use in economy. Social-economic development taking place after First and Second World War, including intense building investment and industrial boom caused increased need and import of asbestos. From 1920 to the $80 \mathrm{~s}$ of twentieth century asbestos import to Poland grew systematically (Fig. 2). It must also be remarked that asbestos-cement boards production started in Poland in 1907 and was continued until 1998, when the Act of 19th June 1997 was passed prohibiting usage of products containing asbestos [32].

Poland belonged to the 'leading' countries applying asbestos products. First asbestos-concrete boards factory after Kuczumow and Nowak [34] was built in Krakow in 1907, next in Lublin in 1910 and just after Second World War another plants in Lublin, Ogrodzieniec, Wierzbica and Szczucin.

Increased asbestos import to Poland started in the $60 \mathrm{~s}$ and lasted until the $90 \mathrm{~s}$ of twentieth century (Fig. 2). In the 60 of twentieth century next big factories of asbestos-cement boards were erected in Trzemeszno, Trzebinia, Jarocin and Pruszków. Total of 24 plants using asbestos in their production functioned in Polish territories. The highest rate of asbestos and its products import was observed between 1970 and 1990 (Fig. 2). Average annual asbestos import amounted about 78 thous. $t$ of the product. As it is reported in the research import decrease was observed after 1990 (Fig. 2). Following the data obtained by Łuniewski and Łuniewski

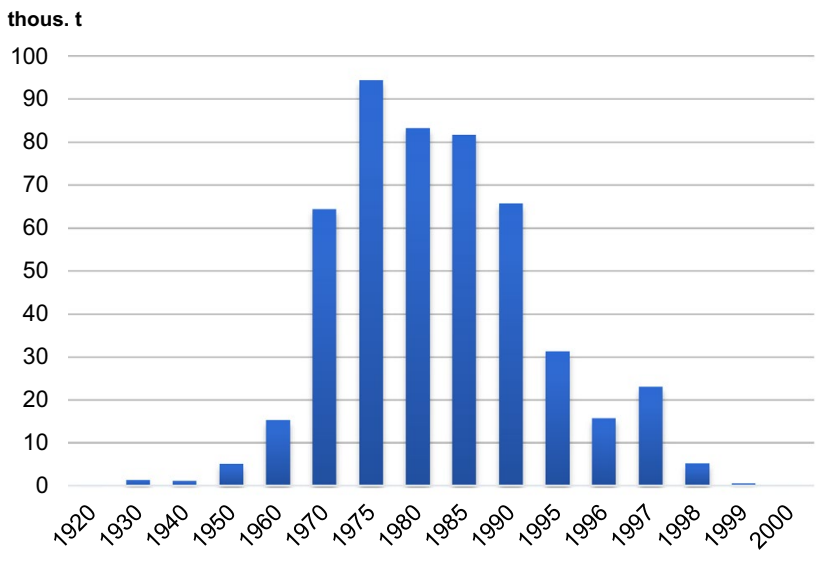

Fig. 2 Asbestos and products containing asbestos import to Poland between 1920 and 2000. Source: own study based on the data [33] 
[35] in the $80 \mathrm{~s}$ of twentieth century, $82 \%$ of asbestos was used in building and constructing, $12 \%$ in chemical industry, $5 \%$ in mechanization and $1 \%$ in other economy branches, while asbestos usage per one inhabitant was estimated in these years in Poland for $1.7 \mathrm{~kg}$, situating the country in 16 position in the world. It must be remarked here, however, that as Albin et al. [36] points out the highest production intensity was reported in the $70 \mathrm{~s}$ of twentieth century, when as much as $85 \%$ participation of asbestos usage was designed for asbestos cement and its derivatives.

It is worth mentioning that in global scale asbestos production in the years of its highest popularity, i.e., in the $70 \mathrm{~s}$ and $80 \mathrm{~s}$ balanced between 4.3 and 4.7 million $t$ annually [4]. Countries like: China, India, Brazil, Argentina, Russia, Kazakhstan, Canada and Zimbabwe were the biggest asbestos and asbestos products manufacturers in 2014. The data reports that in 2014 Canada and Zimbabwe gave up asbestos production, Chile Russia increased it to 1.1 million $t$ of asbestos annually (which is more than a half of total world production) [35].

It must be emphasized once again that Poland introduced relatively early (in 1997) the restrictions for using asbestos and asbestos products and regulations concerning asbestos removal from the country space. It was rather new initiative, whereas USA, for example, limited asbestos production and use in 2002, and EU itself passed respective restrictions as late as in 2005. It should be addend that Denmark was the first country to ban using asbestos for thermal, acoustic insulation, waterproofing (1972) [31]. It also should be remembered that legislation introduced in a number of countries concerning the problem varied, e.g., Croatia in 1993 (bans crocidolite and amosite), in 1996 Slovenia bans production and trade of asbestos products, in 1998 Czech Republic bans the import of asbestos, in 2001 Latvia bans asbestos (exemption for asbestos products already installed, which must, however, be labelled), while Hungary bans amphibolite asbestos products, in 2003 and asbestos-cement products [37]. At present, following the International Ban Asbestos Secretariat production and use of asbestos and asbestos products is banned in 65 countries of the world [31].

\section{State, structure and regional diversity of asbestos products in Poland}

It was estimated for Poland that in 2002 there were 15.5 million $t$ of asbestos products, including: 14,866 thous. y of asbestos-cement boards $\left(1,351,500\right.$ thous. $\left.\mathrm{m}^{2}\right), 600$ thous. $t$ of asbestos-cement pipes and other products [38]. Quantity of pure fibred asbestos import is possible to estimateafter 19452 million $\mathrm{Mg}$ of asbestos was brought to Poland (Fig. 2). On the other hand, it is not possible to obtain the information in case of many other products containing asbestos, because they are often included in smaller import of machinery and other appliances. By 30th June 2017 about 6 million $\mathrm{t}$ of asbestos products were listed, including $90 \%$ in hands of private persons and only $10 \%$ of these products in hands of juridical persons.

Analyzing structure of asbestos products in Poland it should be indicated that $88 \%$ are in form of corrugated sheets, $8 \%$ flat sheets, $2 \%$ pipes and asbestos-cement connectors and 2\% other asbestos objects [39]. Corrugated panels predominate in asbestos products structure in all voivodeships (Table 1), with the highest quantity in Masovian voivodeship (Table 1 ).

The research pointed out that central and eastern Poland regions report the highest number of listed asbestos products, what is a result of certain historical-economic conditioning and reflects to some degree development level of different parts of Poland being under partition by the year 1918 . For instance-in relatively poorly developed part under Russian partition roofs covers were of law quality, with predominant thatch, straw, wooden shakes (what ecological awareness!). Therefore, after Second World War that region reported asbestos-cement (eternit) roofs 'explosion', what was a great progress for those times (1960-1990) and a great problem for present period. After Bański and Wesołowska [42] we could observe in the $60 \mathrm{~s}$ of twentieth century in Lublin region a tendency for replacing old wooden plank or thatched roofs with asbestos-cement roofs.

Present study indicated that there is significant dependence between quantity of listed asbestos and derived products (designed for removal) and a number of buildings from 1970 to 1988, when asbestos was commonly applied for building and engineering purposes (Fig. 3). Value for Pearson correlation coefficient was $r=0.429(p=0.001)$.

The other reason of increased quantity of asbestos in Eastern Poland is the fact that Lublin region is of a rural character, where percentage of asbestos-cement roof covers can amount even 90\% [44]. Rural character is also observed as predominant in Podlasie or Central Poland. High asbestos presence there is confirmed by research of Buczaj et al. [44], where it was established that Lubelski and Warszawski regions report the highest concentration of fibre asbestos structures in the air.

The survey also shows that urbanization level is measured as a ratio of urban population for general population expressed in percentage, what influences on catalogued asbestos quantity and it is confirmed by adjusting curvilinear regression model $r^{2}=0.3845$ with simultaneous statistical significance model below 0.001 (Fig. 4). This connection is also confirmed by value of Pearson correlation coefficient $r=-0.505(p=0.001)$, hence-the lower the degree of urbanization is observed (rural areas), the more of listed asbestos and asbestos products.

Taking above discussion into consideration there are some problems arising. First general issue for Poland is 


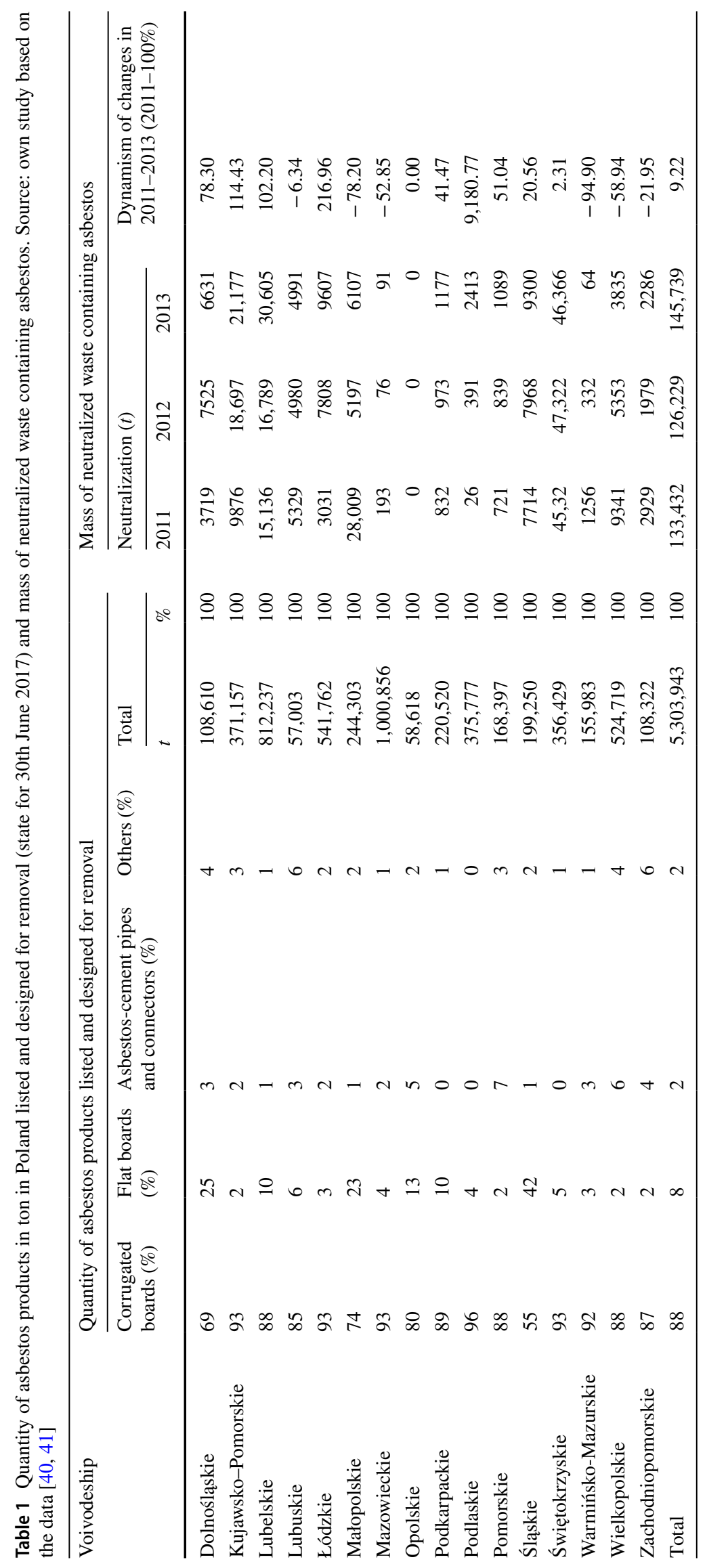


A

B

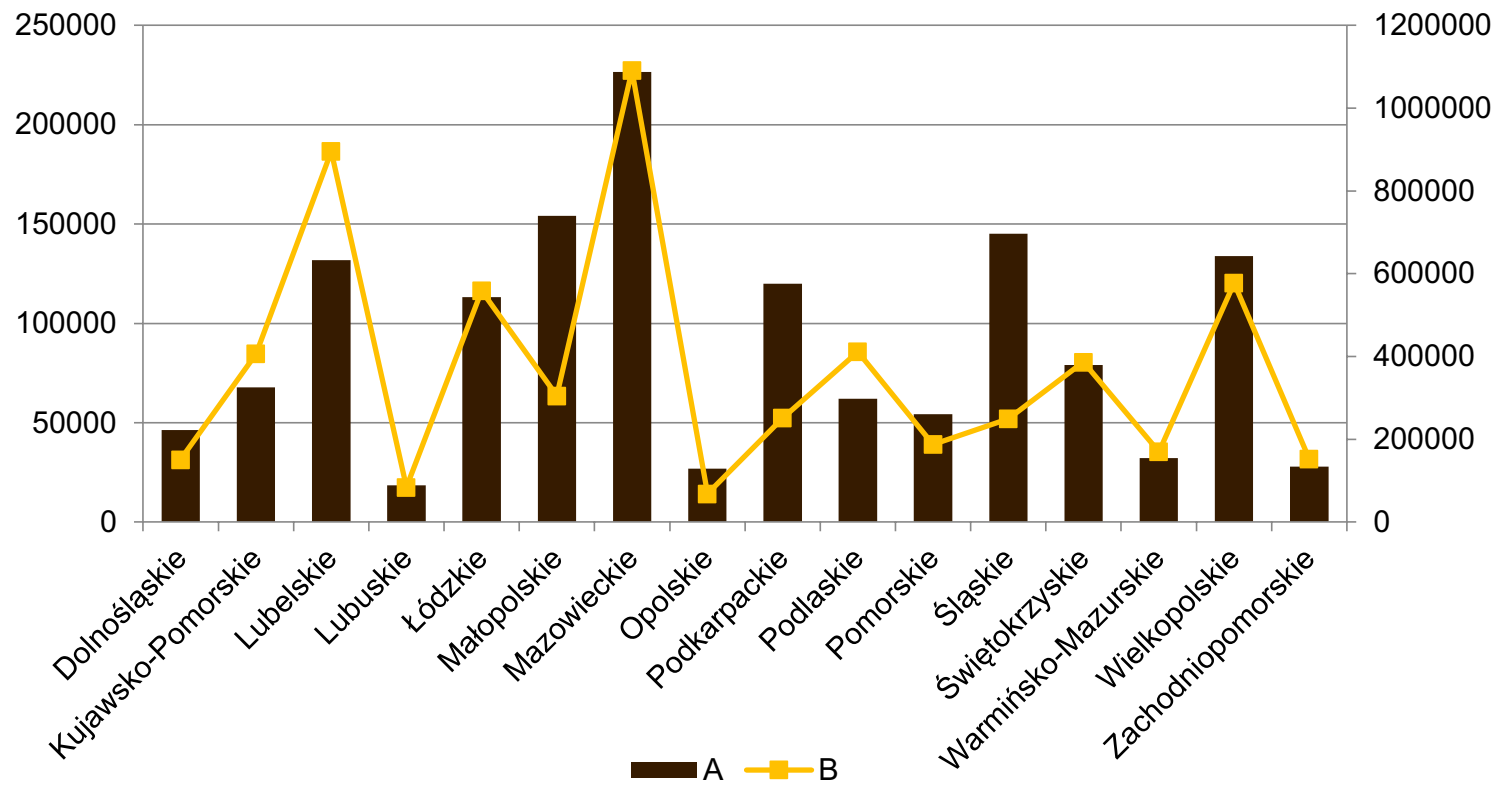

Fig. 3 Number of buildings from 1970 to 1988 and quantity of listed asbestos in Polish voivodeships. Explanations: a Total number of buildings from 1970 to 1988 , b Total quantity of listed asbestos in

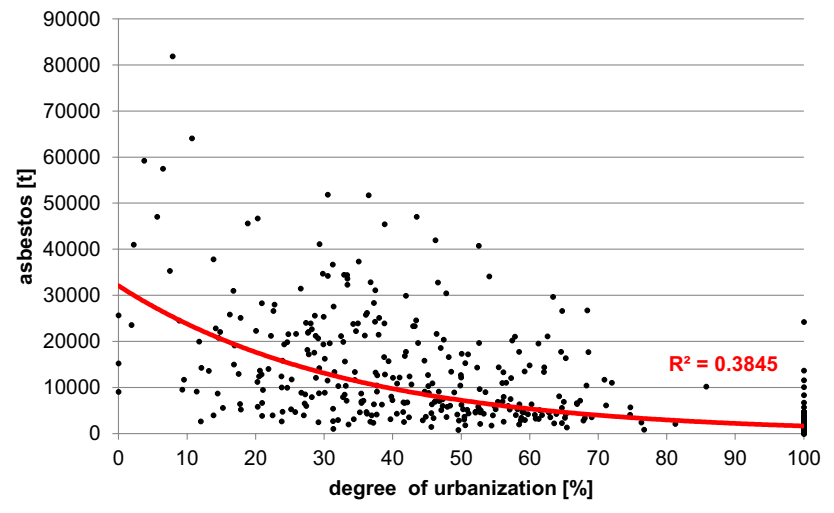

Fig. 4 Dependence between the urbanization degree and quantity of listed asbestos in Poland (in poviats). Source: own study based on the data $[40,43]$

the necessity of making complete inventory of all asbestos products. Until presence (as our survey confirmed) only $1 / 3$ of all asbestos production has been listed in the area of the country. The situation may have resulted from the fact that its presence has not been reported by an owner of a building or other property containing asbestos to respective authority, which consequently follows the material removal or replacing it with other material (the other solution is applied the most often in case of roofs or building fronts), next transport it to specially prepared dumps and secure it, what generates high costs. In some regions of Poland, rural voivodeships in thous. $t$ (state: 30th June 2017). Source: own study based on the data $[40,43]$

ones in particular, there is also an aspect of local society protests, as dismantling asbestos insulation, e.g., roofs leads to general house redecoration, what causes extra costs. Older farmer generations are not so eager to exchange functional and cheap roofs (which serve the purpose) to expensive, but healthier new ones, moreover, that they have not experienced any direct pathogenic consequences of asbestos affects on human health. We should emphasize here that stage of latency can last over 30 years and releases asbestos dusts to the air gradually and it intensifies with time. Therefore, the problem of asbestos disposal has become in Poland and other world countries an issue of economic, financial, social and ecological significance.

While pro-health reasons appeal to a society, relatively small number of disease cases caused by asbestos and their limitation to persons directly working with the material causes the situation that asbestosis and other derivatives are commonly treated as exotic diseases, which significantly diminishes understanding the problem essence and threatening danger.

Another issue, difficult to solve is individual economic interest, because not all Polish communes provide equal cofinancing the costs of asbestos removal. In case of some of them this aid can amount even $100 \%$ of expenses of removing and disposing asbestos, in others there is $80 \%$, and in some cases only from 50 to $20 \%$ of the cost. Sum of that allowance can evidence that officials are resourceful and care for common local good. For example, in Bydgoszcz, the sum 
of allowance for the process is up to $100 \%$ of costs including dismantling, collecting, transport and disposal or storage in a secure location of all waste containing asbestos, but no more than $1000 \mathrm{zl}$ per $1 \mathrm{t}$ of disposed or protected asbestos waste (information obtained basing on field query).

\section{Disposal of asbestos products in Poland}

At this stage of social-economic world development there are many problems requiring rapid reaction and solution. These are, besides desertification and lack of water, nuclear weapon and terror threats as well as ecological challenges. For a human and other living organisms it is vital to reduce and dispose harmful asbestos products used commonly in the past. We all realize the necessity of their instant neutralization. At present the only acceptable method of waste containing asbestos disposal is its storage in special dumps for hazardous waste or separated sectors of other landfills. It must be remembered, though, that just like general definitions of preventing, diminishing and waste reusing differ in various countries and regions $[45,46]$, asbestos disposal methods also differ in various parts of the world. The most efficient methods of asbestos disposal are being discussed in scientific centers, in view of the fact that asbestos waste storage seems to be only a temporal solution. Japan, for instance, promotes asbestos waste inertization and its thermal processing [47, 48]. Research on recycling technology for asbestos waste is being in progress, but due to high costs and special laboratory conditions necessary, the methods are not used in practice [49-53]. Tests of Gidarakos et al. [54] and Paglietti et al. [55] who claim that asbestos mines can be used in future as locations of asbestos waste disposal, which in particular is a safe method of environment pollution minimizing, seem to be exceptionally valuable. Asbestos waste belongs to hazardous waste; therefore, its management requires special procedure and strict control. Following legislation obligatory in Poland, programs for environment protection are implemented with its integral element, which is waste management (plans for waste management on country, voivodeships, poviats and communes level).

An owner of a property is obliged to report asbestos products for removal and disposal (storage) to a special territory administration unit, although, as it was remarked earlier, financial factor is the main obstacle, as an owner is responsible for all the costs concerning asbestos removal, e.g., roof of a building-asbestos panels and replace them with new safe material. One of the ways to hasten the removal process and protect the environment from threat caused by improper asbestos waste management is (what has already been mentioned) support from the part of selfgovernment authorities in co-financing these actions (e.g., financial help with removing asbestos, transport and disposal of all the waste produced during dismantling dangerous construction-rubble and scrap metal in the area of industrial plants or private houses.

Poland has strict legal regulations concerning procedures of dismantling asbestos-cement roof covers, which are included in the Regulation of the Minister of Economy from 14th August 1998 concerning save use and conditions of removing products containing asbestos [56]. In accordance with obligatory executive order removal works must be performed solely by certified firms, equipped with special technical facilities designed for the purpose and qualified staff. There are at present 437 firms functioning in the area of the country for dismantling and transporting asbestos (Fig. 5). These rigorous regulations are designed to reduce negative effects on human health, in particular persons working with the material removal. World evaluations inform that as many as 125 million of people are endangered to harmful asbestos activity in their work places and every year thousands of new cases of asbestos diseases are reported [57].

'The Program for Asbestos Abatement in Poland for 2009-2032' indicated that Poland according to the state for 31 st December 2008 estimated quantity of waste containing asbestos for removal by 2032 amounted about 14.5 million $\mathrm{t}$ (15.5 million in 2002) and they mainly consisted of asbestoscement products, like eternit, so consequently from 2002 to 20081.083 million $\mathrm{Mg}$ of waste containing asbestos were neutralized. 'The Program for Asbestos Abatement in Poland for 2009-2032' assumes that by 2032 the problem of asbestos waste will have been solved definitely, with subsequent process of diminishing-2009-2012 its presence (14.5 million t) decreases of $28 \%$ of asbestos waste ( 4 million $t$ ), in 2013-2022 next $35 \%$ of waste (5.1 million t), while between 2023 and 2032 of $37 \%$ (5.4 million $t$ ).

The survey and analyses show that until now the process of removing and neutralizing asbestos (storage) has been performed much more slowly than it was planned. From 2009 until the half of 2017 only $645,206 \mathrm{Mg}$, i.e., $7.8 \%$ of listed asbestos was neutralized, $84 \%$ of which was asbestos belonging to private persons and only $16 \%$ was natural persons' property.

Researchers' duty requires a remark that quantity of asbestos products already stored was in $200998,322 \mathrm{t}$, in $2010116,457 \mathrm{t}$, in $2011133,432 \mathrm{t}$ and in $2012126,229 \mathrm{t}$ (Table 1); therefore, quantity of removed asbestos forecasted for 2009-2012 was not achieved (!). Between 2009 and 2012 total of 1.557 million $\mathrm{Mg}$ of asbestos products (i.e., about $10.9 \%$ of all mass of the group planned for neutralization for these years) was neutralized (stored). One fact is alarming that by the end of June 2017 even the quantity planned for 2009-2012 for neutralization had not been completed.

On the other hand, it should be emphasized that quantity of neutralized asbestos products in Poland has been gradually growing in majority of voivodeships (Table 1), although there are regions, like: Warmińsko-Mazurskie, 
Fig. 5 Hazardous waste landfills, where asbestos is neutralized and a number of firms removing asbestos in voivodeships (state from 30th June 2017). Explanations: Voivodeships: B-Podlaskie; C-Kuiawsko-Pomorskie; DDolnośląskie; E—-Łódzkie; FLubuskie; G-Pomorskie; KMałopolskie; L-Lubelskie; N-Warmińsko-Mazurskie; $\mathrm{O}$-Opolskie; P-Wielkopolskie; R-Podkarpackie; SŚląskie; T-Świętokrzyskie; W-Mazowieckie; Z-Zachodniopomorskie. Source: own study based on the data [40]

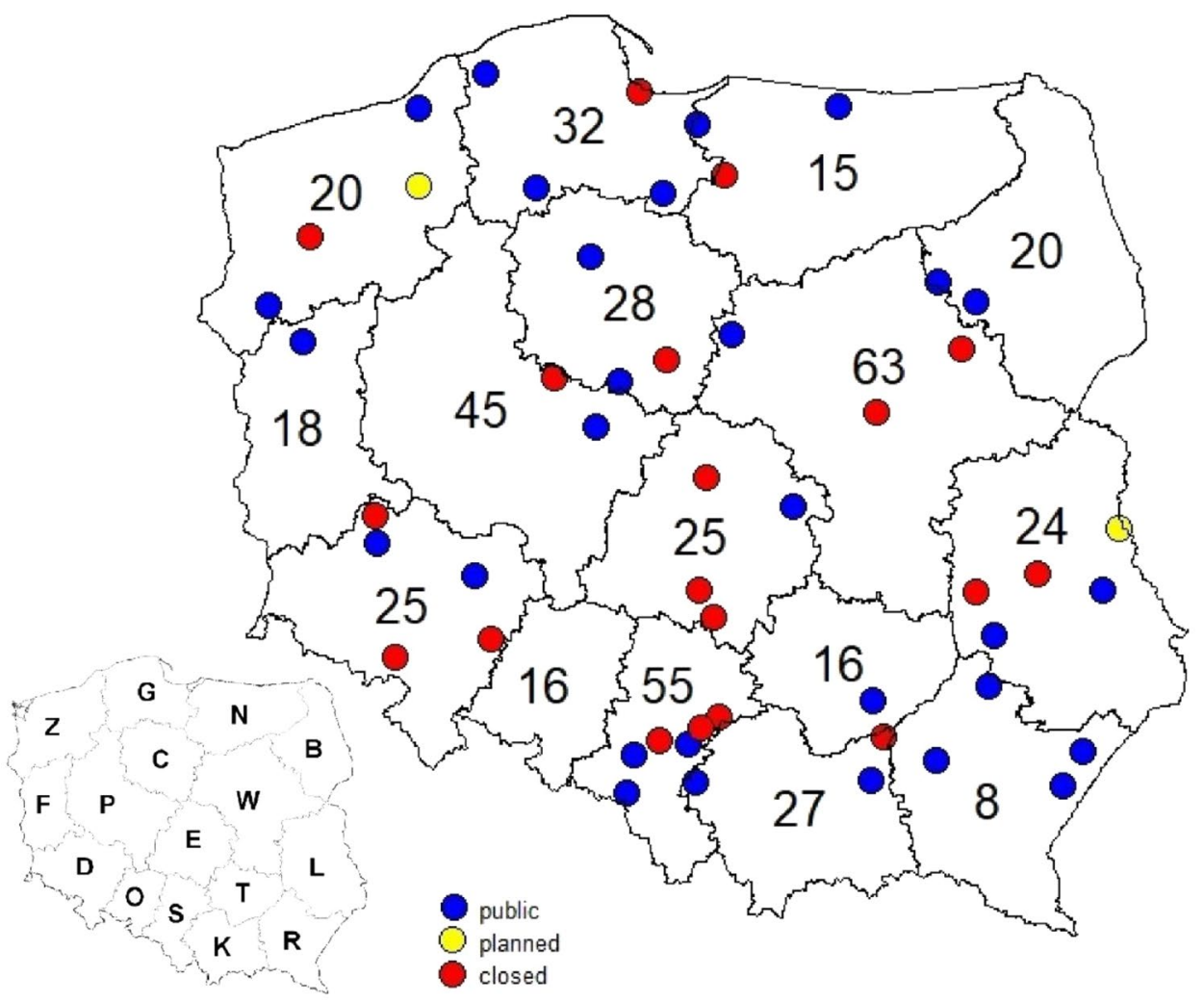

Małopolskie, Mazowieckie Zachodniopomorskie, Lubuskie and Wielkopolskie (Table 1), where the process is slowed down. In the last voivodeship mentioned the drop in asbestos products neutralization (storage) was related to the fact that Wielkopolskie voivodeship stopped in 2013 disposal process for material brought from neighboring regions and started transporting most of asbestos waste to other voivodeships. Another interesting fact is that the voivodeship (Mazowieckie), where the highest number of asbestos was listed, relatively small quantities of that waste are neutralized locally, what indicates that it is transported to neighboring regions. It should be noted that Świętokrzyskie voivodeship is the leading region in asbestos waste disposal, which results from, among the others, financial support and efficient work of special disposing firms. The other example-Opolskie voivodeship does not report any localization of that waste landfill, where it is disposed, so it is transported and stored in another voivodeships (Table 1; Fig. 5).

By the end of June 2017 Polish territory had 34 public hazardous waste landfills functioning, which also neutralized asbestos waste-state for 30th June 2017, located in the following communes: Sianów, Myślibórz, Konin, Bartoszyce, Elbląg, Tuczępy, Świętochłowice, Sosnowiec, Knurów, Jastrzębie-Zdrój, Gdańsk, Chojnice, Kwidzyn, Słupsk, Miastkowo, Zambrów, Pysznica, Radymno, Ostrów, Oleszyce, Sierpc, Bolesław, Tarnów, Oświęcim, Rawa Mazowiecka, Radomsko, Gorzów Wielkopolski, Chełm,
Kraśnik (two), Pruszcz, Piotrków Kujawski, Polkowice, Trzebnica). Pomorskie and Podkarpackie voivodeships have four in each. Until now 19 hazardous waste landfills have been closed and only two new ones are planned. The number of that type of dumping places is still insufficient as for quantity of listed asbestos products in Poland, especially when we assume that future asbestos inventory will be more exact and precise, what in consequence will increase quantity of asbestos for neutralization. The other aspect is significant delay in fulfilling the goals of 'The Program for Asbestos Abatement in Poland for 2009-2032' (which assumed 34 landfills for 2003-2012, while data show that the plan was completed as late as in 2017).

Comparing our results with present world situation in the field, we evidently observe that the majority of Asian and the Pacific countries work without any defined program for asbestos and asbestos-containing products disposal [30]. After Li et al. [30] every country must estimate the situation and its own needs, work out special strategy for removing asbestos form use, define directives concerning asbestos storage, transport, disposal and proper monitoring of the area.

Asbestos harmful impact on human life is observed in European countries, as well. Paglietti et al. [3] point out that despite the fact that Italy banned asbestos use in 1992, asbestos pollution is still present in the country. To limit health negative consequences and improve the situation, 
Italy introduced many anti-asbestos regulations. There are several legal loopholes, however, being obstacles in implementing improving actions, standard procedures concerning risk management do not exist (especially in the stage of waste transport and disposing harmful material). The problem is generated by limited number of hazardous waste landfills and very high charges for asbestos storage. It means illegal landfills for the material localization [3].

Difficulties in introducing proper regulations concerning asbestos disposal are also reported in the UK. Following Kazan-Allen [58] remarks, quoting British Members of Parliament, by 2020 a quarter of a million of British citizens will have died from asbestos diseases, over 6 million tons of asbestos were brought to Great Britain, most of which still remain within the national infrastructure, $75 \%$ of school buildings contain asbestos and every year 5000 persons die from cancers caused by asbestos and respiratory diseases. Facing these threats and despite resolution of European Parliament calling for having removed asbestos from public buildings by 2028 "no such measures have been considered by the British government which continues to defer to the industry-friendly policy of "safe management of a deadly hazard," under which occupational and environmental exposures remain commonplace" [58].

Poland, what is worth mentioning, was the first country in EU to remove asbestos products from public space (European Parliament resolution of 14 March 2013 on asbestosrelated occupational health threats and prospects for abolishing all existing asbestos (2012/2065(INI) in paragraph 4 appealed to EU countries fo follow Polish example and evaluate the results and analyze costs and profits of the plan by 2028 for safe asbestos removal from all public buildings with regular customers' access, provide information and directives for private building owners, encouraging them for effective controls detecting asbestos presence in their properties.

Many world countries have their general obligatory regulations concerning asbestos, but they lack detailed directives referring to asbestos disposal from the environment. According to Li et al. [30], supervision over obliga tory law is still insufficient, and introducing particular regulations becomes difficult due to deficiency in proper funds and qualified staff.

\section{Conclusions}

In the light of above discussion, four problems concerning asbestos products procedures arise. First-mechanisms of co-financing asbestos removal are implemented slowly and in insufficient sums. Similar problems are reported in other post-socialistic countries, where fight with asbestos is performed more in institutional-legal dimension, than in practical one. Second-Poland has not had complete inventory list containing all asbestos products and locations. Third-not all communes and poviats have prepared their own programs of removing asbestos from their territories. Fourth-the society is characterized by a relatively low awareness concerning harmful effects of asbestos waste for human health and life, dangers resulting from improper procedures, particularly in the context of releasing harmful substances caused by atmospheric conditions. All these factors make the fight with asbestos still present and important.

It must be emphasized once again, that to achieve the goals of various programs accepted to remove asbestos from the country one must intensify the efforts in making complete lists of asbestos occurrence, implement new financial mechanisms supporting communes and private persons encouraging them to remove asbestos materials, educate and raise awareness of both-self-government authorities, local societies and entrepreneurs. Without this complex look at the problem of asbestos existence we will not achieve for long successful results and harmful asbestos activity will be still felt by generations of 22 nd century.

Acknowledgements This work was supported by the National Science Centre of Poland [grant numbers 2015/19/N/HS4/02586].

Open Access This article is distributed under the terms of the Creative Commons Attribution 4.0 International License (http://creativeco mmons.org/licenses/by/4.0/), which permits unrestricted use, distribution, and reproduction in any medium, provided you give appropriate credit to the original author(s) and the source, provide a link to the Creative Commons license, and indicate if changes were made.

\section{References}

1. Sporn TA (2014) The mineralogy of asbestos. In: Oury T, Sporn T, Roggli V (eds) Pathology of asbestos-associated diseases. Springer, Berlin

2. Gherevenka V (2005) The asbestos problem-the look from Europe. Real estate and investments. Legal regulation. 23. http:// dpr.com/.ru/journal/journal_23_22.htm

3. Paglietti F, Malinconico S, della Staffa BC, Bellagamba S, De Simone P (2016) Classification and management of asbestoscontaining waste: European legislation and the Italian experience. Waste Manag 50:130-150. https://doi.org/10.1016/j.wasma n.2016.02.014

4. Haynes RC (2010) A worn-out welcome: renewed call for a global ban on asbestos. Environ Health Perspect 118(7):298-303. https ://doi.org/10.1289/ehp.118-a298

5. Szeszenia-Dąbrowska N (2003) Azbest a zdrowie człowieka. Materiał dydaktyczny na kurs specjalistyczny. Bezpieczne postępowanie $\mathrm{z}$ azbestem i materiałami zawierającymi azbest. AGH, Kraków (in Polish)

6. Pyssa J, Rokita GM (2007) The asbestos-occurence, using and the way of dealing with asbestic waste material. Gospodarka Surowcami Mineralnymi 23/1:49-61. https://meeri.eu/Wydaw nictwa/GSM231/pyssa-rokita.pdf. Accessed 18 June 2017

7. Gualtieri AF, Giacobbe C, Sardisco L, Saraceno M, Gualtieri ML, Lusvardi G, Cavenati C, Zanatto I (2011) Recycling of the product of thermal inertization of cement-asbestos for various 
industrial applications. Waste manag 31(1):91-100. https://doi. org/10.1016/j.wasman.2010.07.006

8. Zhang YL, Kim YC, Hong WH (2016) Visualizing distribution of naturally discharged asbestos fibers in Korea through analysis of thickness changes in asbestos cement slates. J Clean Prod 112:607-619. https://doi.org/10.1016/j.jclepro.2015.08.004

9. Kim YC, Hong WH (2017) Optimal management program for asbestos containing building materials to be available in the event of a disaster. Waste Manag 64:272-285. https://doi.org/10.1016/j. wasman.2017.03.042

10. Promentilla MAB, Peralta GL (2003) An evaluation of landfill disposal of asbestos-containing waste and geothermal residues within a risk-assessment framework. J Mater Cycles Waste Manag 5:13-21. https://doi.org/10.1007/s101630300003

11. Vogel L (2005) Special report—asbestos in the world. Hesa Newslett 27:7-21

12. Szeszenia-Dąbrowska N, Sobala W (2010) Zanieczyszczenie środowiska azbestem. Skutki Zdrowotne. Raport z badań. Wyd, 2. Oficyna Wydawnicza MA, Łódź (in Polish)

13. Ministry of Economy (2010) Program for Asbestos Abatement in Poland for 2009-2032. https://www.bazaazbestowa.gov.pl/image s/do-pobrania/PROGRAM_ENG.pdf Accessed 30 June 2017

14. USGS (2015) Minerals Yearbook [Advance Release] Asbestos. U.S. Geological Survey, Reston, Virginia. pp 8.1-8.6

15. Doll R (1955) Mortality from lung cancer in asbestos workers. Br J Ind Med 12:81-86

16. Rödelsperger K, Jöckel KH, Pohlaben H, Römer W, Woitowitz HJ (2001) Asbestos and manmade vitreous fibers as risk factors for diffuse malignant mesothelioma: results from a German hospital-based case control study. Am J Ind Med 39:262-275. https ://doi.org/10.1002/1097-0274(200103)39:3\%3C262::AID-AJIM1 014\%3E3.0.CO;2-R

17. Więcek E (2004) Asbestos-exposition and health effects. Bezpieczeństwo pracy 2:2-6 (in Polish)

18. Bianchi C, Bianchi T (2007) Malignant mesothelioma: global incidence and relationship with asbestos. Ind Health 45(3):379-387. https://doi.org/10.2486/indhealth.45.379

19. Gibbs GW, Berry G (2008) Mesothelioma and asbestos. Regul Toxicol Pharmacol 52(1):223-231. https://doi.org/10.1016/j.yrtph .2007 .10 .003

20. Pierce JS, McKinley MA, Paustenbach DJ, Finley BL (2008) An evaluation of reported no effect chrysotile asbestos exposures for lung cancer and mesothelioma. Crit Rev Toxicol 38:191-214. https://doi.org/10.1080/10408440701845609

21. Baumann F, Ambros JP, Carbone M (2013) Asbestos is not just asbestos: an unrecognised health hazard. Lancet Oncol 14(7):576578. https://doi.org/10.1016/S1470-2045(13)70257-2

22. Stayner L, Welch LS, Lemen R (2013) The worldwide pandemic of asbestos-related diseases. Annu Rev Public Health 34:205-216. https://doi.org/10.1146/annurev-publhealth-031811-124704

23. Baek SC, Kim YC, Choi JH, Hong WH (2016) Determination of the essential activity elements of an asbestos management system in the event of a disaster and their prioritization. J Clean Prod 137:414-426. https://doi.org/10.1016/j.jclepro.2016.07.117

24. Szymańska D, Korolko M, Grzelak-Kosulska E, Lewandowska A (2016) Ekoinnowacje w miastach. Wydawnictwo UMK, Toruń (in Polish)

25. Newhouse ML, Thompson H (1965) Mesothelioma of pleura and peritoneum following exposure to asbestos in the London aea. $\mathrm{Br}$ J Ind Med 22:261-269

26. Selikoff IJ, Lee DHK (1978) Asbestos and disease. Academic Press, New York

27. Constanza MC, Stayner LT, Straif K, Reina M, Al-Alem U, Demers PA, Landrigan PJ (2011) Occupational exposure to asbestos and ovarian cancer: a meta-analysis. Environ Health Persp 119:1211-1212. https://doi.org/10.1289/ehp.1003283
28. Frank AL, Joshi TK (2014) The global spread of asbestos. Ann Glob Health 80(4):257-262. https://doi.org/10.1016/j. aogh.2014.09.016

29. Virta RC (2003) Worldwide asbestos supply and consumption trend from 1900 to 2000 . USGC Survey

30. Li J, Dong Q, Yu K, Liu L (2014) Asbestos and asbestos waste management in the Asian-Pacific region: trends, challenges and solutions. J Clean Prod 81:218-226. https://doi.org/10.1016/j. jclepro.2014.06.022

31. International Ban Asbestos Secretariat (2018) http://www.ibase cretariat.org/. Accessed 30 July 2018

32. Act on the ban of use of asbestos-containing products of June 19th, 1997. (Law Gazette 1997 No. 101 pos. 628). http://isap. sejm.gov.pl/DetailsServlet?id=WDU19971010628. Accessed 6 July 2017 (in Polish)

33. USGS (2006) Worldwide Asbestos Supply and Consumption Trends from 1900 through 2003. U.S. Geological Survey, Reston

34. Kuczumow A, Nowak J (2013) Azbest - właściwości, utylizacja (in Polish). Towarzystwo Naukowe Organizacji i Kierownictwa Stowarzyszenie Wyższej Użyteczności Dom Organizatora

35. Łuniewski A, Łuniewski S (2008) Asbestos: historical burden from the 20th century. Wydawnictwo Ekonomia i Środowisko, Białystok (in Polish)

36. Albin M, Magnani C, Krstev S, Rapiti E, Sheferl I (1999) Asbestos and cancer: an overview of current trends in Europe. Environ Health Perspect 107(2):289-298. https://www.ncbi.nlm.nih.gov/ pmc/articles/PMC1566265/pdf/envhper00519-0069.pdf Accessed 20 July 2017

37. European Federation of Building and Woodworkers (2013) Asbestos-related occupational diseases in Central and East European Countries

38. [Council of Ministers of Poland (2002) Program usuwania azbestu i wyrobów zawierających azbest stosowanych na terytorium Polski (in Polish) https://www.mpit.gov.pl/media/15234/Program_2002. pdf. Accessed 30 July 2018

39. Lewandowska A (2016) PhD thesis Transformations of Polish cities and regions in the light of eco-development conception, Torun (in Polish)

40. Base A, https://esip.bazaazbestowa.gov.pl/geoserwis.html (in Polish) Accessed 06 Aug 2017

41. KPGO report (2016) http://www.monitorpolski.gov.pl/ MP/2016/784 (in Polish) Accessed 30 July 2017

42. Bański J, Wesołowska M (2010) Transformations in housing construction in rural areas of Poland's Lublin region-influence on the spatial settlement structure and landscape aesthetics. Landsc Urban Plan 94:116-126. https://doi.org/10.1016/j.landurbpla n.2009.08.005

43. Central Statistical Office of Poland. http://stat.gov.pl/. Accessed 20 June 2017

44. Buczaj A, Brzana W, Tarasińska J, Buczaj M, Choina P (2014) Study on the concentration of airbone respirable asbestos fibres in rural areas of the Lublin region in south-east Poland. Ann Agric Environ Med 21(3):639-643. https://doi.org/10.5604/12321 966.1120617

45. Sakai SI, Yano J, Hirai Y, Asari M, Yanagawa R, Matsuda T, Kunisue T (2017) Waste prevention for sustainable resource and waste management. J Mater Cycles Waste Manag 19(4):1295-1313. https://doi.org/10.1007/s10163-017-0586-4

46. Lewandowska A (2018) Economics of waste management in Poland in the context of regional ecologization as exemplified By Kujawsko-Pomorskie Voivodship. Electron J Pol Agric Univ 21(1). http://www.ejpau.media.pl/volume21/issue1/art-01.html. Accessed 30 July 2018

47. Osada M, Takamiya K, Manako K, Noguchi M, Sakai SI (2013) Demonstration study of high temperature melting for 
asbestos-containing waste (ACW). J Mater Cycles Waste Manag 15(1):25-36. https://doi.org/10.1007/s10163-012-0088-3

48. Yamamoto T, Kida A, Noma Y, Terazono A, Sakai SI (2018) Evaluation of thermally treated asbestos based on fiber number concentration determined by transmission electron microscopy. J Mater Cycles Waste Manag 20(1):214-222. https://doi. org/10.1007/s10163-016-0564-2

49. Su Q, Long X (2009) On the approach for comprehensive utilization of asbestos tailing. Multipurp Util Miner Resour 1:27-31

50. Zhu W (2009) Application research of asbestos tailing in highway concrete. Shanxi Archit 8:181-182

51. Viani A, Gualtieri A, Pollastri S, Rinaudo C, Croce A, Urso G (2013) Crystal chemistry of the high temperature product of transformation of cement asbestos. J Hazard Mater 248:69-80. https:// doi.org/10.1016/j.jhazmat.2012.12.030

52. Zhai W, Wang Y, Deng Y, Gao H, Lin Z, Li M (2014) Recycling of asbestos tailings used as reinforcing fillers in polypropylene based composites. J Hazard Mater 270:137-143. https://doi. org/10.1016/j.jhazmat.2014.01.052

53. Gaggero L, Ferretti M (2018) The self-sustained high temperature synthesis (SHS) technology as novel approach in the management of asbestos waste. J Environ Manag 216:246-256. https:// doi.org/10.1016/j.jenvman.2017.09.019
54. Gidarakos E, Anastasiadou K, Koumantakis E, Nikolaos S (2008) Investigative studies for the use of an inactive asbestos mine as a disposal site for asbestos wastes. J Hazard Mater 153(3):955-965. https://doi.org/10.1016/j.jhazmat.2007.09.060

55. Paglietti F, Malinconico S, Di Molfetta V, Giangrasso M (2012) Guidelines for asbestos remediation at Italian superfund sites. J Environ Sci Health Part C Environ Carcinog Ecotoxicol Rev 30(3):253-286. https://doi.org/10.1080/10590501.2012.705161

56. Regulation of the Minister of Economy from 14th August 1998 concerning save use and conditions of removing products containing asbestos (in Polish) (Law Gazette No. 138, pos. 895) http:// isap.sejm.gov.p1/DetailsServlet?id=WDU19981380895. Accessed 29 July 2017

57. LaDou J, Castleman B, Frank A, Gochfeld M, Greenberg M, Huff J, Joshi TK et al (2010) The case for a global ban on asbestos. Environ Health Perspect 118(7):897-901. https://doi.org/10.1289/ ehp.1002285

58. Kazan-Allen L (2016) Eradicating the asbestos hazard. Br Asbestos Newslett 99. http://www.britishasbestosnewsletter.org/ban99 .htm. Accessed 30 July 2018 